\title{
Gambaran Pengetahuan Ibu Hamil Tentang Nurisi Dalam Persiapan Laktasi Di RSIA Aura Syifa Kabupaten Kediri
}

\author{
Erna Rahmawati \\ Program Sudi D III Kebidanan, Institut Ilmu Kesehatan Bhakti Wiyata Kediri \\ Email: ernanarto44@gmail.com
}

\begin{abstract}
ABSTRAK
Latar Belakang: Laktasi merupakan proses menyusui mulai dari produksinya ASI sampai bayi menghisap ASI.Memberikan ASI merupakan hal yang sangat baik untuk menciptakan sumber daya manusia yang berkualitas. Tujuan: Melihat dan menilai pengeahuan ibu hamil tentang nurisi dalam persiapan laktasi serta untuk mengetahui sejauh mana ibu mengeahui manfaat ASI. Metode:Dalam peneliian ini merupakan jenis penelitian deskriptif,tekhnik pengambilan sample yang digunakan dalam peneliian ini adalah aksidental sampling.

Hasil: Dari Hasil penelitian menunjukkan bahwa tingkat pengetahuan ibu hamil tentang nutrisi dalam persiapan laktasi dikategorik pada tahap cukup,terlihat dari data yang diperoleh sebanyak katerogi baik 7 responden $(10,6 \%), 52$ responden $(78,7 \%)$ dan kategori kurang 7 responden $(10,6 \%)$ dari 66 responden. Kesimpulan dan saran: Pemberian informasi oleh tenaga kesehatan yang berkaitan dengan persiapan laktasi masih kurang.Ini akan berdampak buruk pada pemberian ASI,hal ini terlihat dari daa d atas pengetahuan ibu hamil tentang persiapan lakasi dikategorikan cukup. Perlu upaya untuk meningkatkan pengetahuan ibu hamil tenang persiapan laktasi guna menunjang pemberikan ASI eksklusif.
\end{abstract}

Kata Kunci: Pengetahuan ibu hamil,Nurisi Persiapan laktasi

\begin{abstract}
Background: Lactation is a breastfeeding process starting from the production of breast milk until the baby sucks breast milk. Providing breast milk is a very good thing to create quality human resources. Objective: To see and assess the knowledge of pregnant women about nurisi in lactation preparation and to find out the extent to which mothers know the benefits of breastfeeding. Method: In this research is a type of descriptive research, the sampling technique used in this research is accidental sampling.

Results: From the results of the study showed that the level of knowledge of pregnant women about nutrition in lactation preparation was categorized at a sufficient stage, it can be seen from the data obtained as good as 7 respondents (10.6\%), 52 respondents $(78.7 \%)$ and less categories 7 respondents $(10.6 \%)$ of 66 respondents. Conclusions and suggestions: The provision of information by health personnel relating to lactation preparation is still lacking. This will have a negative impact on breastfeeding, this can be seen from the knowledge of pregnant women about active preparation is categorized sufficient. Efforts need to be made to increase the knowledge of calm pregnant women in lactation preparation to support exclusive breastfeeding.
\end{abstract}

Keywords: Knowledge of pregnant women, Nutrisi Lactation preparation 


\section{PENDAHULUAN}

Kehamilan merupahan hal yang sangat menggembirakan bagi calon orang tua serta keluarga ${ }^{1}$.Calon ibu hendaknya memiliki pengetahuan dan kesipan yang cukup melewai proses kehamilan,persalinan dan menyusui bayinya segera setelah bayi lahir ${ }^{2}$.Persiapan menyusui merupakan hal yang penting dan harus dipersiapakan sejak pada masa kehamilan ${ }^{3}$.

Pada studi pendahuluan yang telah dilakukan di RSIA Aura Syifa Kabupaten Kediri dari $30 \mathrm{ibu}$ hamil terdapat $15 \mathrm{ibu}$ hamil belum mengetahui persiapan nutrisi sejak dini penting dalam persiapan proses laktasi ${ }^{4}$ Banyak faktor yang mempengaruhi ibu hamil tentang nutirisi dalam persiapan laktasi salah satunya adalah kurangnya pengetahuan ibu hamil tentang nutrisi yang harus dipersiapan sebelum proses menyusui ${ }^{5}$.

Berdasarkan data diatas peneliti tertarik melakukan peneliian dengan judul "Gambaran Pengetahuan Ibu Hamil Tentang Nutrisi Dalam Persiapan Laktasi Di RSIA Aura Syifa Kabupaten Kediri"'. Tujuan dari penelitian ini adalah menganalisa gambaran pengetahuan ibu hamil tentang nutrisi dalam persiapan laktasi ${ }^{7}$.

\section{METODE Dan BAHAN PENELITIAN}

Penelitian ini tergolong penelitian deskriptif dan pengambilan sample dengan menggunakan Nonprobabiltty sampling. Populasi yang diambil dalam penelitian ini adalah semua ibu hamil baik yang primipara maupun yang mulitipara yang melakukan pemeriksaan di RSAI Aura Syifa sebanyak 66 responden.Alat untuk mengumpulkan data penelitian ini menggunakan kuesioner.

\section{HASIL PENELITIAN}

Data yang diambil pada penelitian ini di bagi menjadi yaiu data umum dan data khusus.Data umum dilihat berdasarkan usia,tingkat pendidikan, pekerjaan

memperoleh informasi dan sumber informasi disajikan pada tabel 1 dan data khusu dilihat berdasarkan kriteria pengetahuan disajikan pada tabel 2 .

\section{Data Umum}

Tabel 1.Prosentase karakteristik responden berdasarkan usia, tingkat pendidikan,pekerjaan,memperole $\mathrm{h}$ informasi,dan sumber informasi.

\begin{tabular}{|c|c|}
\hline Keterangan & $\%$ \\
\hline \multicolumn{2}{|l|}{ a. Usia } \\
\hline$<20$ tahun & 24,3 \\
\hline 20-35 tahun & 47,4 \\
\hline$>35$ tahun & 28,3 \\
\hline Total & 100 \\
\hline \multicolumn{2}{|c|}{ b. Tingkat pendidikan } \\
\hline SD & 7,5 \\
\hline SLTP & 24,2 \\
\hline SMA & 52,1 \\
\hline Perguruan tinggi & 15,1 \\
\hline Total & 100 \\
\hline \multicolumn{2}{|l|}{ c. Pekerjaan } \\
\hline IRT & 37 \\
\hline Buruh & 6,5 \\
\hline PNS & 6,5 \\
\hline Karyawan swasta & 18 \\
\hline Wiraswasta & 13 \\
\hline Total & 100 \\
\hline \multicolumn{2}{|c|}{ d. Memperoleh informasi } \\
\hline Pernah & 100 \\
\hline Tidak Pernah & 0 \\
\hline Total & 100 \\
\hline \multicolumn{2}{|l|}{ e. Sumber Informasi } \\
\hline Media masa & 28,7 \\
\hline Tenaga kesehatan & 40,9 \\
\hline Teman & 30,4 \\
\hline Total & 100 \\
\hline \multicolumn{2}{|c|}{$\begin{array}{l}\text { Berdasarkan dari data tabel diatas } \\
\text { menunjukkan bahwa hampir seluruhnya } \\
\text { responden berusia } 20-35 \text { tahun sebanyak } \\
31 \text { responden }(47,4 \%) \text {, sebagian besar } \\
\text { responden diketahui berpendidikan SMA } \\
\text { sebanyak } 35 \text { responden }(5,1 \%) \text {,dari segi } \\
\text { informasi hampir seluruhnya responden } \\
\text { sudah mendapatkan informasi tenang } \\
\text { nutrisi dalam persiapan laktasi sebanyak } \\
66 \text { responden (100\%),dan responden } \\
\text { mendapatkan informasi dari tenaga } \\
\text { kesehatan sebesar } 27 \text { respinden }(40,9 \%) \text {. }\end{array}$} \\
\hline
\end{tabular}




\section{Data Khusus}

Tabel .2 prosentase pengetahuan ibu hamil tenang nutrisi dalam persiapan laktasi

\begin{tabular}{|c|c|c|}
\hline Kriteria & $\mathrm{n}$ & $\%$ \\
\hline Baik & 7 & $10,6 \%$ \\
\hline Cukup & 52 & $78,7 \%$ \\
\hline Kurang & 77 & $10,6 \%$ \\
\hline Total & 66 & $100 \%$ \\
\hline \multicolumn{3}{|c|}{$\begin{array}{l}\text { Berdasarkan tabel } 2 \text { menunjukkan bahwa } \\
\text { sebagian besar responden }\end{array}$} \\
\hline $\begin{array}{l}\text { berpengetahuancukup } \\
\text { responden }(78,7 \%) \text {. }\end{array}$ & sebanyak & 52 \\
\hline
\end{tabular}

\section{PEMBAHASAN}

Pengetahuan merupakan sesuatu yang diketahui manusia atau hasil pekerjaan yang sudah dilakukan manusia untuk menjadi panutan.Faktor - faktor yang mempengaruhi pengetahuan yaitu usia, tempat tinggal,sumber informasi,pekerjaan dan pendidikan.Dari hasil penelitian sebagian besar responden memiliki usia 20-35 tahun. Rentang usia 20-35 tahun adalah usia yang dianggap produktif dan memiliki tingkat kematangan yang lebih matang dalam hal bersikap,berfikir. Semakin bertambahnya usia maka orang menjadi lebih dewasa dan memiliki banyak pengalaman.Dari hal tersebut menjadikan pengetahuan seseorang menjadi bertambah.

Tingkat pendidikan juga memiliki andil terhadap tingkat pengetahuan seseorang,dengan tingkat pengetahuan yang tinggi dapat menambah wawasan dan pengetahuan seseorang, dengan pengetahuan dan tingkat pendidikan yang dimiliki menjadi tolok ukur keberhasilan seseorang dalam memahami sesuau informasi tentang gizi ibu hamil tentang laktasi.

Faktor yang bisa mempengaruhi pengetahuan selain usia, tingkat pendidikan dan pekerjaan yaitu sumber informasi yang diperoleh responden.Sumber informasi bisa diperoleh melalui konseling,media cetak,media elektronik,media papan,keluarga, teman serta petugas kesehatan.Seseorang yang memiliki sumber informasi yang lebih akan diimbangi oleh pengetahuan yang baik.

\section{SIMPULAN}

Berdasarkan dari penelitian yang dilakukan peneliti menyimpulkan bahwa sebagian besar ibu hamil di RSIA Aura Syifa Kabupaten Kediri memiliki pengetahuan cukup,sebagian besar dari mereka mengetahui informasi pentingnya nutrisi untuk persiapan lakasi dari petugas kesehatan.Petugas kesehatan mempunyai peran yang sangat penting dalam pengopimalan dan meningkatkan pelayanan kesehatan dalam hal ini khusunya dalam bidan pemenuhan gizi guna meningkatkan produksi ASI.

\section{SARAN}

1. Bagi tenaga kesehatan

Tenaga kesehatan diharapkan mampu memberikan penjelasan atau informasi pada kunjungan ANC dengan cara memberikan leaflet serta memberikan konseling enang nutrisi guna persiapan laktasi

2. Bagi peneliti selanjutnya

Peneliti selanjutnya diharapkan bisa mengembangkan dan menggali masalah lain yang bisa menumbukan pengetahuan ibuenang persiapan laktasi sejak hamil.

\section{REFERENSI}

Sulistyawati, 2014. Asuhan Kebidanan Pada Masa Kehamilan. Jakarta : Salemba Medika.

Arikunto, S. 2010. Prosedur Penelitian Suatu Pendekatan Pendekatan Praktek. Jakarta : Krineka Cipta.

Ayu Putri Ariani, 2014. Aplikasi Metodologi Penelitian Kebidanan Dan Kesehatan Reproduksi. Jogjakarta: Nuha Medika. 
Depkes RI. 2015. Profil Kesehatan Indonesia. Jakarta :Depkes RI.

Dinkes Provinsi Jawa Timur. 2015. Profil Kesehatan Jawa Timur.Tahun 2015. http:/www.dinkeskedirikab.go.id.(Di akses tanggal 30 Desember 2015. Pukul 09.00).

Kusmiati. 2010. Nutrisi Ibu Hamil. Jogjakarta: Fitra Maya.

Notoadmodjo, Soekido. 2007. Metodologi Penelitian Kesehatan. Jakarta : Rineka cipta.

Nur Salam. 2008. Konsep Dan Penerapan Metodiologi Penelitian Ilmu Keperawatan. Jakarta : Salemba Madika.

Padmawati, 2013. Persiapan Menyusui. Jogjakarta: Nuha Medika.

Partiwi. 2007. Buku Tentang Menyusui. Jogjakarta : Graha Ilmu.

Prawirohardjo, Sarwono. 2008. Buku Asuhan Kebidanan. Jakarta : PT. Bina Pustaka Sarwono Prawirohardjo.

Proverawati, 2009. Gizi Kebidanan. Yogjakarta: Nuha Medika.
Saryono. 2010. Metodologi Penelitian Kesehatan Penuntun Praktis Bagi Pemula. Jogjakarta : Mitra Cindekia Press.

Setiasih Try Kumiati. 2011. Pengetahuan Nutrisi Ibu Pada Masa Kehamilan.

Simkin, Dkk. 2007. Panduan Lengkap Kehamilan, Jakarta : ARCAN.

Siregar. 2008. Faktor Persiapan Menyususi. Jogjakarta : Salemba.

Sudibyo. 2013. Buku Ajaran Metodologi Riset Keperawatan. Jakarta : Salemba Medika.

Sugiyono. 2014. Metode Penelitian Kuantitatif, Kualitatif Dan $R \& D$. Bandung : Alfabeta.

Suryati Romauli. 2011. Asuhan Kebidanan 1. Yogyakarta: Nuha Medika.

Weni Kristiansari, S. Kep. 2009. Asi Menyususi Dan Sadari, Jogjakarta : Nuha Medika.

World Health Organization, 2015. Nutrisi ibu hamil. http : //www.who.go.id / index. Php ? vw $=2 \& \mathrm{id}=790$ diakses tanggal 27 maret 201522.16 WIB. 